\title{
Chapter 22 \\ Estimating Seagrass Blue Carbon and Policy Implications: The Australian Perspective
}

\author{
Peter J. Ralph, J. R. Crosswell, T. Cannard and Andrew D. L. Steven
}

\begin{abstract}
Blue carbon policy supports carbon sequestration whilst also conserving our remaining seagrass meadows. The complex biogeochemical processes within the sediment of seagrass meadows are responsible for the longevity of the stored carbon. Carbon stock and accumulation rates are controlled by the interaction of hydrodynamic, geochemical and biotic processes unique to each meadow. Carbon content (stock and flux) of a meadow must be quantified for inclusion in carbon accounting, whether for market trading or national greenhouse gas accounting. Management of seagrass blue carbon also requires estimates of additionality, leakage, permanence, conversion and emission factors.
\end{abstract}

\subsection{What Is Blue Carbon?}

Blue carbon is carbon that has been captured and sequestered by coastal marine vegetated habitats, which include seagrass meadows, mangrove forests and salt marshes. These habitats can be highly productive and have been identified as strong carbon sinks, as some seagrass species and regions support remarkably high carbon

P. J. Ralph ( $\square)$

Climate Change Cluster, University of Technology Sydney, Broadway, NSW 2007, Australia

e-mail: Peter.Ralph@uts.edu.au

J. R. Crosswell

CSIRO Oceans and Atmosphere, 3-4 Castray Esplanade, Hobart,

TAS 7001, Australia

e-mail: Joey.Crosswell@csiro.au

T. Cannard · A. D. L. Steven

CSIRO Oceans and Atmosphere, EcoSciences Precinct, GPO Box 2583,

Brisbane, QLD 4001, Australia

e-mail: Toni.Cannard@csiro.au

A. D. L. Steven

e-mail: Andy.Steven@csiro.au 


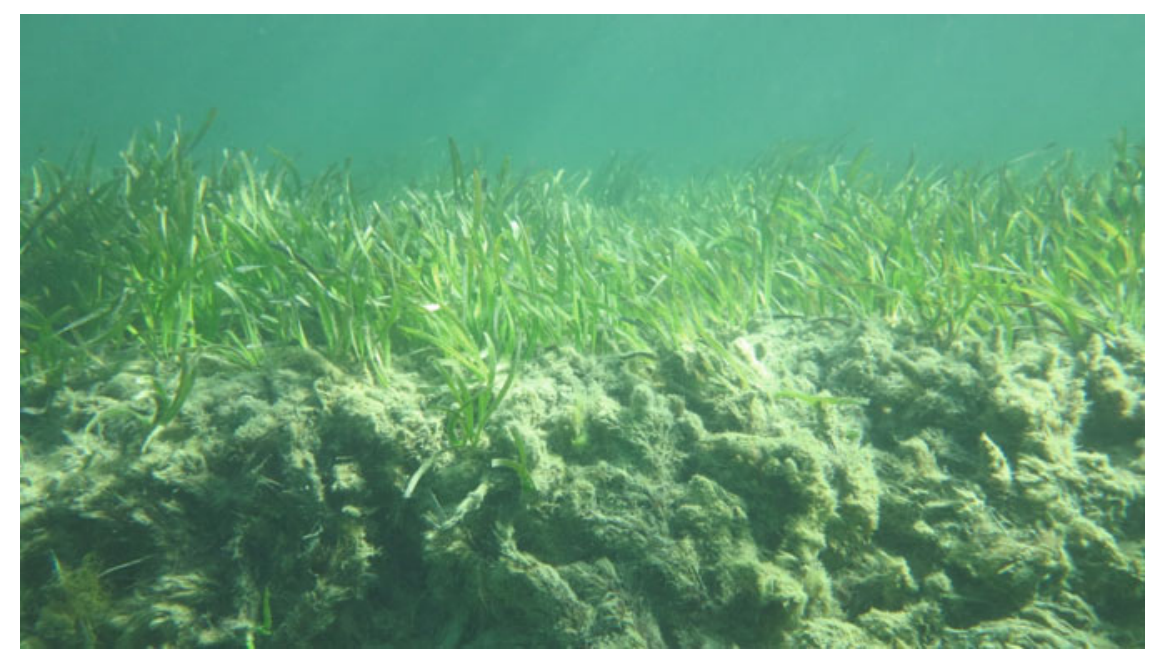

Fig. 22.1 Posidonia escarpment in Shark Bay, Western Australia, with living plants at the surface, and a deep layer of organic-rich sediment underneath, exposed by erosional processes. Photograph by Paul Lavery (ECU)

burial rates. Blue carbon can be stored for millennia, unlike terrestrial "green" carbon which turns over more rapidly through cycles of plant growth and decay. In blue carbon habitats, particularly seagrass, most of the carbon is stored in belowground biomass (Fig. 22.1) and in anoxic sediment where microbial decomposition of litter (or remineralisation) is extremely slow (Enríquez et al. 1993). These low decomposition rates, combined with high primary productivity, allow blue carbon habitats to build up large, persistent carbon stocks.

Biogeochemical cycles of seagrass meadows have been studied for the past few decades. However, there has been a resurgence in seagrass research driven by the recent connection between long-term carbon storage in seagrass meadows and efficiency of this carbon for natural sequestration (e.g. McLeod et al. 2011; Duarte et al. 2010, 2011; Kennedy et al. 2010). This recent research has led to a better understanding of the biogeochemical mechanisms, magnitudes, and uncertainties associated with carbon capture in blue carbon habitats.

\subsection{Seagrass Drive Natural Carbon Sequestration}

Seagrass are responsible for about $15 \%$ of the total carbon stored in the ocean, although they represent less than $0.2 \%$ of the total area of the ocean (Garrard and Beaumont 2014). Seagrass sequester up to 35 times more carbon per area into long-term storage as compared to tropical forests (McLeod et al. 2011). Unfortunately, coastal marine habitats are some of the most threatened ecosystems 
on Earth. These habitats are being degraded at a rate that is equivalent to four times that of tropical forests, and climate change continues to exacerbate this situation. Since the 1980s, the global rate of seagrass loss is 7\% per year (Waycott et al. 2009) and losses are even greater in some areas of Australia's increasingly urbanised coastline. For example, around half of the seagrass meadows in New South Wales have been lost relative to their historical coverage (Zann 2000). Apart from reducing potential carbon storage, the loss of seagrass also degrades an extensive range of other ecosystem services (including storm protection, maintaining coastal water quality and supporting coastal fisheries). The value of these services continues to increase given their role as a buffer against impacts of global climate change. Seagrass meadows also have the ability to bolster long-term coastal geomorphological resilience through erosion management and wave energy reduction (Arkema et al. 2013; Grimsditch et al. 2013), and potentially, mitigation from sea level rise (Orth et al. 2006). Therefore, these critical habitats need to be protected in order to safeguard carbon stores and ensure their ongoing ecological function and thereby maintain their associated highly valued ecosystem services.

\subsection{Overview of Carbon Biogeochemistry in Seagrass Meadows}

Healthy seagrass meadows require good water quality, including suitable levels of nutrients, sufficient light and stable sediments to maintain productive meadows. Loss of seagrass meadows can be triggered by acute disturbances or through chronic impacts of climate change and anthropogenic modification to coastal ecosystems (Barbier et al. 2011). Direct removal of seagrasses can occur during coastal development activities such as dredging or boat moorings. Indirect effects of human activity on seagrass occur through reduced water quality, such as eutrophication (nutrient pollution), and episodic sediment plumes from catchment runoff, which reduce light and smother the plants.

Carbon stocks and accumulation rates in seagrass meadows are controlled by a range of factors (Fig. 22.3). Accumulation rates depend on environmental characteristics of the meadow, such as water depth and velocity, as well as the physical characteristics of the seagrass (Serrano et al. 2014). Different species of seagrass accumulate carbon at different rates in relation to their growth form, compositional makeup of tissues (recalcitrance) and sediment type (Lavery et al. 2013; Trevathan-Tackett et al. 2017). Understanding the hydrodynamics of a site will improve estimates of local carbon accumulation and stocks. However, accumulation rates can also be influenced by other abiotic factors, including sediment grain size and sediment type (terrigenous or calcareous). It is more difficult to monitor and establish causality between these indirect relationships.

Blue carbon stored in seagrass meadows is classified as either autochthonous or allochthonous depending on its source. Autochthonous carbon is carbon that has 
been biologically fixed within the seagrass meadow, but was previously dissolved in the water column (Fig. 22.3). Allochthonous carbon is carbon that was biologically fixed in connected environments, but has been hydrologically transported to and deposited in the seagrass meadow. It has been estimated that up to $50 \%$ of the carbon within a seagrass meadow is autochthonous and 50\% allochthonous. Seagrass have a burial efficiency of up to $10 \%$ of the fixed carbon that is stored within the plant, whereas other marine plants, such as pelagic phytoplankton, have burial rates of about $0.5 \%$. Burial efficiency in seagrass meadows can vary depending on several biological factors, including bioturbation, bacterial diversity and the degradation rate of autochthonous and allochthonous carbon types (Mateo et al. 2006).

\subsection{Australian Seagrass Blue Carbon Habitats}

Australia has an extensive marine area which contains a significant fraction of all global vegetated coastal ecosystems. Lavery et al. (2013) estimated Australian seagrasses to contain $155 \mathrm{Mt}$ of carbon; given a diverse range of species-specific $\mathrm{C}_{\text {org }}$ storage rates to a depth of $25 \mathrm{~cm}$ (for comparison Ajani and Comisari 2014 used $100 \mathrm{~cm}$ depth). For example, it has been estimated that $1-2 \%$ of all global seagrass carbon stocks are contained within Shark Bay alone due to its large area of seagrass meadows and high accumulation rates. However, carbon stocks vary across Australia's 9,256,900 hectares of seagrass meadows (Lavery et al. 2013). Current Australian datasets show a large range in sediment organic carbon content, ranging from 1.09 to $20.14 \mathrm{mg} \mathrm{C}_{\text {org }} \mathrm{cm}^{-3}$ (Lavery et al. 2013; Serrano et al. 2014). Smaller stature seagrass species generally have lower organic carbon stocks, but they can also cover a large area of the tropical northern coastline; they are estimated to account for $46 \%$ of Australia's seagrass carbon. The remaining 54\% is thought to be mostly stored in large-stature, meadow-forming temperate species such as Posidonia and Amphibolis.

\subsubsection{How Is the Carbon Budget Estimated at a Seagrass Site?}

To build a carbon budget, three characteristics of the meadow must be determined: the area of the meadow, an estimate of the carbon stored in the sediment and the rate that the sediment is accreting or eroding. This process to build a carbon budget is described in more detail below:

1. Map site boundaries and assess heterogeneity using satellite remote sensing or aerial photos. Estimating boundaries can be complex due to water depth or tidal variation when observing sparse intertidal species. Satellite remote sensing 
provides a synoptic view of a sufficiently wide area to provide national estimates of seagrass coverage, but may not have the resolution for regional estimates. Remote sensing can also be used to routinely confirm the extent of the managed seagrass meadows over time, especially when linked to a carbon financing scheme. Historical aerial photos and satellite remote sensing can also be used to identify lost, degraded or converted meadows, as well as the effectiveness of restoration or habitat recovery.

2. Quantify carbon inputs from other habitats. Riverine particulate organic carbon (POC) and oceanic phytoplankton, zooplankton and detritus are typically the main sources of allochthonous carbon moving into a meadow. If there is significant input from other nearby blue carbon habitats, or if there are multiple riverine inputs, then stable isotopes, molecular tracers and elemental ratios can be used to determine carbon sources. Partitioning allochthonous carbon sources ensures that carbon uptake/release is not double counted for multiple ecosystems.

3. Quantify metabolism of the site. If possible, it is useful to quantify seagrass photosynthesis, seagrass respiration and microbial respiration, as this assists in estimating autochthonous input.

4. Estimate carbon stocks and fluxes. Carbon concentrations can vary with depth; sediment cores provide a vertical profile that considerably improves stock estimates. Radio-isotopes can be used to determine the age of carbon down the sediment profile and accretion rates can be estimated based on the change in carbon concentration over time. In highly productive and heterogeneous habitats, gas fluxes between the sediment, water and air may also need to be quantified in order to determine ecosystem metabolism over shorter timescales (Macreadie et al. 2014).

Finally, once the areal extent is determined (and regularly measured to identify changes), we can estimate the value of the blue carbon resource by scaling a limited number of stock (and flux) estimates to cover the area under management control.

\subsection{Blue Carbon Markets}

Blue carbon financing offers a mechanism to protect and capitalise on other ecosystem services provided by coastal marine vegetated habitats. In developing policy to support blue carbon markets, there is an opportunity to incentivise the promotion of healthy coastal marine vegetated habitats, as well as blue carbon storage and production. In Australia, it is no coincidence that significant areas of seagrass meadows are situated in regions that exhibit outstanding universal values (OUV) and are recognised in World Heritage listings, e.g. Great Barrier Reef, Shark Bay, Ningaloo coast, and the Great Sandy Straits. Accordingly, economic non-market values have been revised from $\$ 13,786$ per hectare in 1997 to $\$ 193,843$ per hectare in 2016 (Pendleton et al. 2016). The increases in estimated value have 
arisen as now more of the thirteen components of total economic value for coastal wetlands have been monetised (Costanza et al. 1997; Pendleton et al. 2016). The development of robust and rigorous non-market estimates will be further hastened with a deeper understanding of seagrass carbon stocks and flows.

The Blue Carbon Initiative and the Blueprint for Ocean and Coastal Sustainability are both international programs calling for protection, and restoration of carbon-rich coastal and ocean habitats. These programs also call for the development of global blue carbon markets (Lau 2013; Ullman et al. 2013; IOC/ UNESCO 2011; Conservation International 2015). Quantifying coastal carbon stocks found in mangroves, saltmarsh and seagrass is a vital step toward establishing this market (Fig. 22.2), but there remain several obstacles. For example, the transient nature of seagrass meadows (fluctuate seasonally and spatially), poses particular challenges for monitoring coverage and assessing the permanence of carbon stocks. Accordingly, understanding boundaries and carbon fluxes for each blue carbon habitat are crucial factors required for both policy and market development.

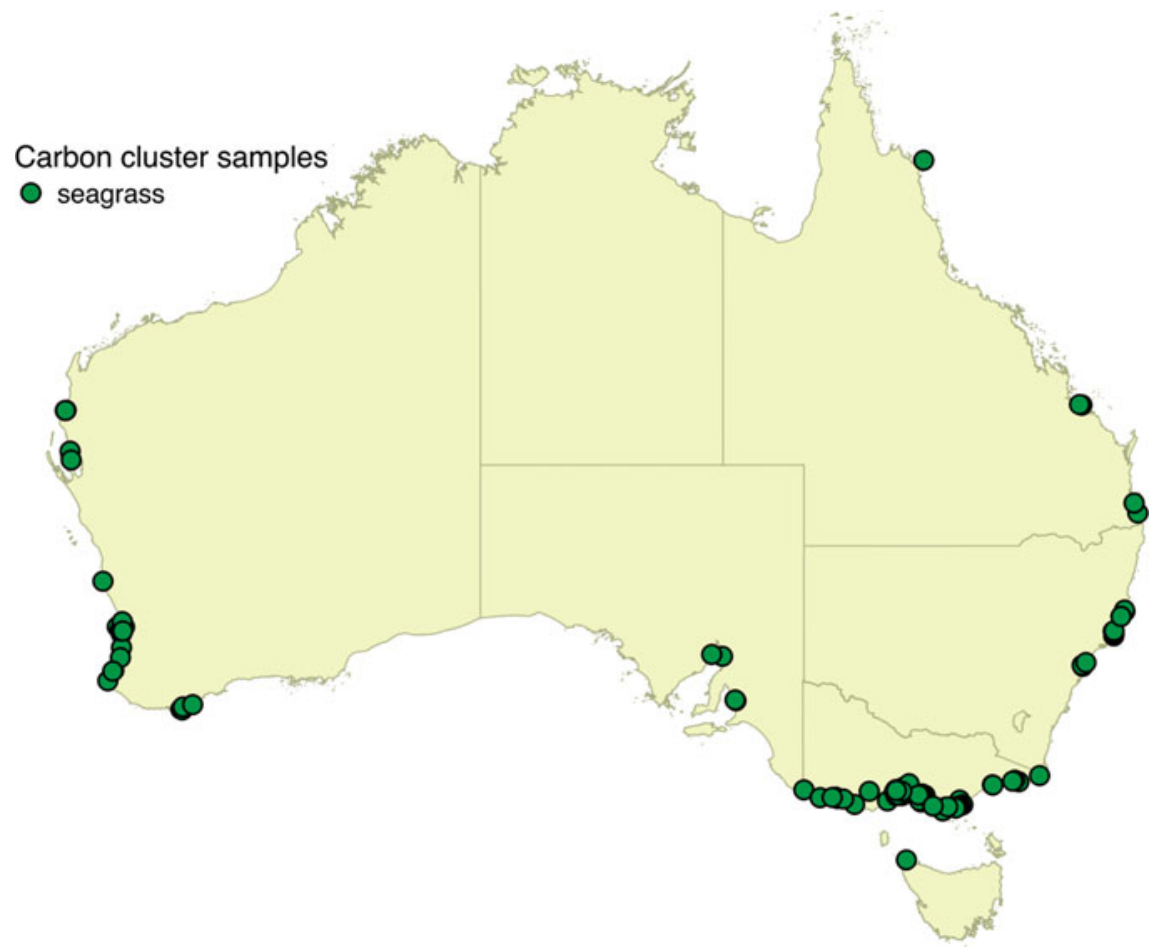

Fig. 22.2 Map showing the distribution of sediment cores collected at Australian sites to estimate seagrass $\mathrm{C}$ stock 


\subsection{International Policy and the Impact on Australia}

In the 2006 IPCC Guidelines for National Greenhouse Gas inventories, seagrass were not mentioned. Without direct recognition of seagrass as a blue carbon habitat in IPCC guidelines, there have been no incentives for carbon financing, conservation of carbon stocks, or the restoration of meadows.

In 2009, UNEP published a report entitled "Blue Carbon: A rapid response assessment" (Nellemann et al. 2009) which described how seagrass were a critical component of blue carbon coastal vegetation. This report was the catalyst for the inclusion of blue carbon into the IPCC, NGOs and intergovernmental policy advisors. It also provided a list of key recommendations to ensure blue carbon protocols were developed. This triggered the establishment of the Blue Carbon Initiative which comprised two working groups: scientific and policy. The Blue Carbon Initiative (CI, IUCN, UNESCO-IOC) has been driving the evolution of both policy and the underlying science to allow blue carbon habitats to be incorporated into national greenhouse gas inventories, and to enable blue carbon trading on carbon markets. At the international level, policy frameworks are being developed to improve the management of these vulnerable coastal habitats and to create financial and other incentives to conserve, restore and sustainably use these ecosystems (Pendleton et al. 2016).

In 2013, a Wetlands Supplement to the 2006 IPCC Guidelines for National Greenhouse Gas inventories was adopted which included coastal wetlands, specifically seagrasses, mangroves and salt marshes. Methodologies for coastal wetlands require approval from UNFCCC for inclusion in IPCC reporting. There are three tiers of assessment in IPCC reporting: Tier 1-national estimates based on a global database; Tier 2-national estimates based on regional/country-based data; and Tier 3 - estimates from high-resolution observations and models repeated over time. Nationally relevant data is essential to develop Tier 2 estimates, and ultimately, Tier 3 requires habitat-specific estimates. In order to adopt the 2013 Wetlands Supplement, habitat-specific emission factors and sequestration rates are required to calculate both stocks and fluxes. Indeed, the Wetlands supplement triggered much of the research required to support policy development for the inclusion of seagrass in national carbon accounting. Similarly, Reduce greenhouse gas Emissions from Deforestation and forest Degradation (REDD) was established under the United Nations Framework for Climate Change Convention (UNFCCC). Of note, Luisetti et al. (2013) calculated that the removal of incentivised approaches such as REDD could result in extensive loss of blue carbon ecosystems and associated economic value losses as high as US\$1 billion by 2060 .

The current EU carbon stock accounting framework draws heavily on the System of Environmental-Economic Accounting (SEEA) Central Framework and the System of National Accounts (SNA) and enacts the principle of completeness or comprehensiveness (Lau 2013; Ullman et al. 2013; IOC/UNESCO 2011). Furthermore, the definition, classification, scope and valuation of environmental assets, contained in the Australian Environmental-Economic Accounts (AEEA), is defined by the aforementioned SEEA Central Framework. 


\subsection{Development of an Australian Blue Carbon Policy for Seagrass}

A Blue Carbon policy must address several complex issues to ensure it is consistent with other IPCC-based mitigation strategies (Ullman et al. 2013). The terms described below have been developed for forest-based mitigation and have been translated into blue carbon habitats. Values for each terms are required for national carbon accounting, as well as market evaluation. Australia is yet to release an integrated blue carbon strategy and policy to mitigate climate change. Much of the necessary groundwork has been completed over the past three years as part of the CSIRO Marine and Coastal Carbon Biogeochemistry Cluster (including Trevathan-Tackett et al. 2015; Rozaimi et al. 2016). The following issues need to be examined by the UNFCCC in support of carbon accounting: emission factors, additionality, leakage, permanence and conversion (defined below). These issues are also the main elements in "net flow accounting" which avoids double-counting the amount of converted carbon, but would recognise carbon loss due to leakage and conversions (ABS 2015).

When a seagrass meadow is degraded or destroyed, the sediment organic carbon can be remineralised to inorganic carbon. Depending on water chemistry, some of this inorganic carbon can be emitted to the atmosphere as $\mathrm{CO}_{2}$. The portion of the original amount of organic carbon stock that is remineralised and subsequently lost to the atmosphere is called the "emission factor" (Fig. 22.3). For example, Cebrian (2002) estimated that the loss of mangroves around the globe has released $3.9 \times 10^{8}$ tonnes $\mathrm{C}$ into the atmosphere from long-term blue carbon stocks. Establishing emission factors for Australian seagrass will require development of new carbon accounting protocols. These new protocols must be able to quantify how much seagrass carbon is lost to the atmosphere when a habitat is degraded/ destroyed, and how much carbon is redistributed to another oceanic carbon stock. Historical evidence of lost meadows can provide an opportunity to estimate seagrass emission factors. Methane emissions are generally assumed to be minor, but more research is still needed to confirm this assumption. There are few Australian estimates of emission factors. One recent example, Macreadie et al. (2015), found that seagrass in Jervis Bay NSW that had been destroyed over 50 years ago due to seismic testing had lost $72 \%$ of their original carbon stock, which dates back 100,000 years. They also found that recovered Posidonia australis meadows had only $35 \%$ of the carbon that an undisturbed meadow contained, yet more than twice that of disturbed areas. More of these estimates are needed across different habitats, climatic bioregions and for different causes of decline.

The term "additionality" refers to the requirement that the sequestration of carbon must be "in addition" to what would occur without offsets or policy action. That is, the sequestered carbon must be greater than the business-as-usual scenario for the country (Fig. 22.4). 


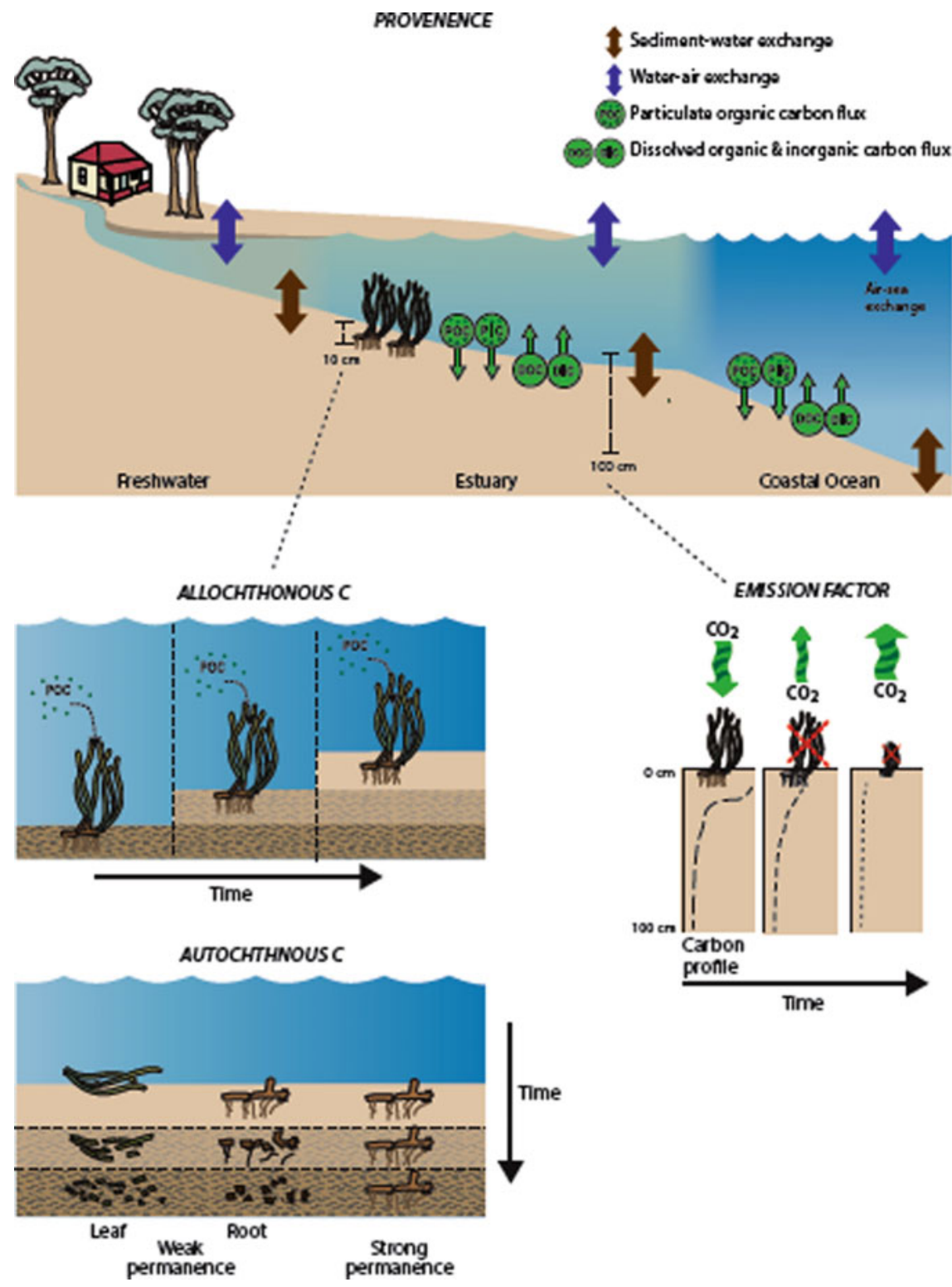

Fig. 22.3 Provenance of seagrass carbon is shown across an estuary, where carbon enters from the terrestrial catchment and moves into the estuary where if it is not trapped then it can settle in the coastal ocean seafloor. Carbon can move from the water column into the sediment and it equilibrates with the atmosphere. Particulate organic carbon (POC) enters the sediment, while dissolved organic carbon and dissolved inorganic carbon is liberated from the sediment into the water column. The allochthonous carbon panel illustrates the process of sediment accretion and seagrass vertical migration. The autochthonous carbon panel illustrates the process of organic tissue breakdown of leaves and roots showing both weak and strong permanence. Finally, the panel showing emission factors demonstrates how the down-core carbon profile of a seagrass meadow contains more carbon than a recently degraded meadow, and significantly more that an aged degraded site 

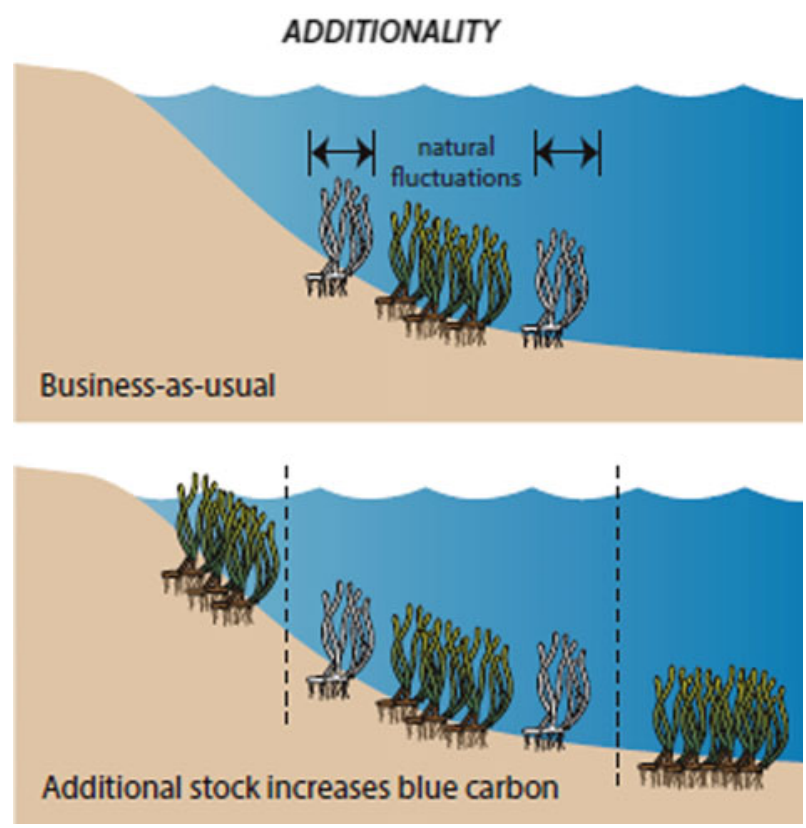

Fig. 22.4 Additionality is illustrated in the lower panel where more seagrass biomass accumulated than the natural fluctuation (lighter coloured seagrass) in biomass that occurs over season and between years (upper panel)

"Leakage" occurs when activities within a project's accounting boundary affect regions outside of that boundary, and cause a change in the greenhouse gas (GHG) emissions of those external environments. Leakage is often unanticipated and difficult to quantify, particularly in hydrologically-connected coastal ecosystems. However, it is important that leakage is measured and included in the net GHG impact of a project. An increase in external GHG emissions is known as negative leakage, because it counteracts GHG benefits achieved within the project accounting boundary. Positive leakage occurs when external GHG emissions decrease as a result of a project activity. Positive leakage is an added benefit in a project's net GHG impact (Fig. 22.5).

The "permanence" of the carbon sequestered must be estimated and the risk of the loss must be minimised. Seagrass sediment carbon is well recognised as having high permanence due to the recalcitrance of the stored carbon (Trevathan-Tackett et al. 2015). However, some species are ephemeral, so the meadow will not always remain year-to-year. The degree to which the sediment carbon diminishes when the 


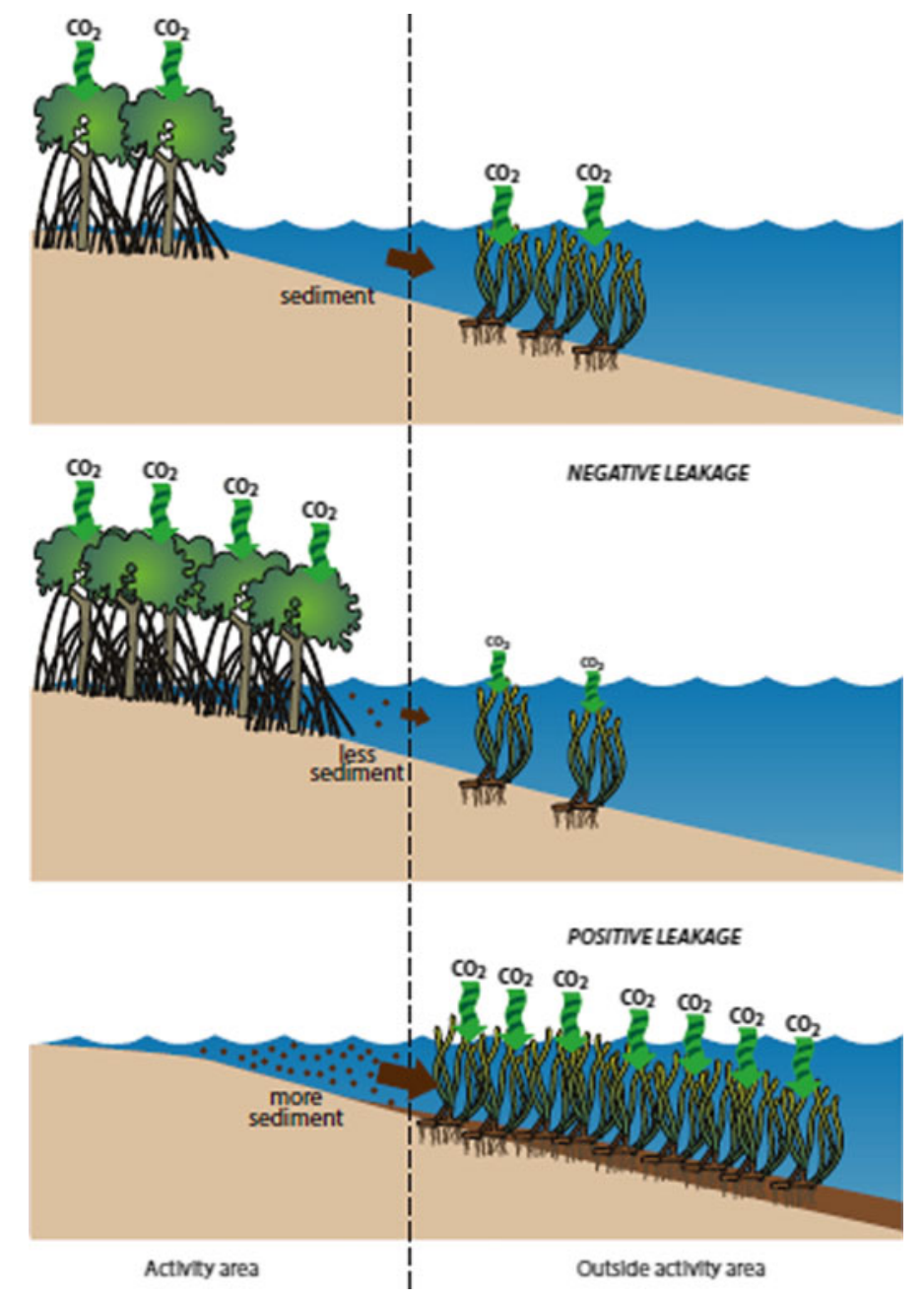

Fig. 22.5 Leakage is illustrated in this panel, where leaves fall into the upper catchment, this created particulate organic carbon (brown dots) that is transported into the upper estuary (mangrove compartment), where mangrove leaves become part of the detritus within the mangrove carbon pool. Carbon that moves into the seagrass compartment has leaked from the mangroves. Pelagic phytoplankton move between the coastal ocean and the seagrass compartments

meadow disappears is currently unknown. Methods have recently been developed to assess the longevity of the carbon stored within the sediment cores. For example, thermogravemetric analysis can identify the lignocellulose matrix with seagrass sediments (Trevathan-Tackett et al. 2015). Furthermore, Macreadie et al. (2012) showed that shifts in the source of detritus altered the recalcitrance of sequestered 
carbon. The study also found that the source of allochthonous carbon in some seagrass meadows shifted during the past 200 years of human industrialisation from mangrove-dominated detritus to microalgae-dominated detritus.

Habitat "conversion" occurs when a blue carbon habitat is destroyed and replaced with an alternate function, such as removal of mangroves to establish shrimp ponds. The quantity of "carbon loss upon conversion" (Pendleton et al. 2012) must be estimated, but there are currently few Australian or global estimates. Conversion may only affect carbon stocks to a certain depth, but the depth at which conversion is no longer important is yet to be defined. Additionally, emission factors for converted habitats depend on how the habitat is converted. For example, dredging a seagrass meadow would likely release more of the carbon stock compared to less destructive conversions. Further research is needed to estimate the emission factors associated with different types of conversion.

Protecting seagrass also results in avoided emissions. In this case, a habitat's carbon stock is assessed, and if a land-management or a development proposal is considered for this region, the avoided emissions of the potential conversion can be assessed in the overall impact of the development. Avoided emissions vary depending on habitat carbon stock, the rate of carbon released to the atmosphere, the risk of future habitat loss and the cost of establishing a protection zone around the habitat. Preserving seagrass habitats can provide low-cost opportunities to mitigate $\mathrm{CO}_{2}$ emissions.

\subsection{Blue Carbon Accounting Processes in Australia}

The National Carbon Accounting System (NCAS) currently accounts for Australian land-based GHG emissions (sources) and removals (sinks). The Australian Greenhouse Emissions Information System (AGEIS) was designed for Australia to meet IPCC requirements for national greenhouse inventory systems and reporting emissions. In addition to preparing the Australian National Inventory Report to meet the IPCC requirements, the Department of the Environment reports greenhouse gas (flux) information using the ANZSIC classification (ABS 2015). Accurate accounting requires knowledge of the biogeochemical cycles, satellite remote sensing and climatology, which are integrated using the Full Carbon Accounting Model (FullCAM; Ajani and Comisari 2014). Mangrove carbon stock estimates will be included for the first time in the next round of GHG reporting for Australia. However, questions still remain regarding boundaries between the different types of coastal, marine and terrestrial ecosystems, and boundary rules must still be developed. Similarly, thought must be given to how territory definitions encompass tidal movements and shifting seagrass meadows. 
Carbon sinks must pass a 'permanency' test (e.g. 100 years in REDD) in order to qualify for carbon crediting systems (Grimsditch et al. 2013). It is unclear whether seagrass carbon reserves will be afforded special requirements for this test, as one might argue whether this is appropriate given the ephemeral and shifting nature of some seagrass species. Nevertheless, there is an urgent need to increase seagrass protection, restoration and monitoring efforts given their critical role in the global carbon cycle (Selig et al. 2014).

It is realistic to expect that seagrass will eventually be included in the national GHG accounting scheme, at which point all detected gains and losses of habitat will be incorporated into the national carbon budget. It is possible to create a blue carbon map of Australia's coastal wetlands following the principles developed for Australia's current terrestrial soil carbon map. Restoration (provided it is additional) would be counted as an increase in carbon storage and will be considered separately. Policies developed to encourage active carbon bio-sequestration such as the Carbon Farming Initiative are currently only relevant to mangroves and saltmarsh. Adopting coastal blue carbon measures for this recognition in the already well-established Carbon Farming Initiative may convince farmers to return ponded pastures to mangrove habitats. Given the many benefits of seagrass meadows, the advantages of linking of carbon storage with habitat conservation, biodiversity protection and valuation of ecosystem services is widely recognised (Barbier et al. 2011). Once included in the national carbon accounting, blue carbon will become an effective tool to enhance the conservation of seagrass.

\subsection{Seagrass Blue Carbon Management}

Economic policy and other incentives (e.g. stewardship-based incentives) that recognise the value of coastal blue carbon stocks and further sequestration are being developed in Australia and in many countries around the globe. It is hoped that a number of critical management actions, listed below, can be implemented to support and to promote blue carbon markets including the option for compensatory actions:

1. Identify the key regional threats to seagrass loss, e.g. dredging, boat mooring or coastal development. Monitor seagrass meadows on a regular basis to assess damage before effects cannot be reversed.

2. Identify vulnerable meadows with large carbon stocks as "high risk" and give such regions elevated protection status. This generally means areas of high carbon accumulation are allocated a high protection status as this would be a significant "avoided emission".

3. Avoid destructive harvesting methods (e.g. purse seine netting) within seagrass meadows. 
4. Support research to develop and test low cost, strategically-placed seagrass restoration that will promote natural recruitment and meadow development. Restoration of seagrass habitat could be an effective solution, but the process is complex. Generally $35-50 \%$ of restoration efforts are successful, and these have only covered small areas (Irving et al. 2010). In some cases, restored seagrass burial rates have been found to be similar to that of established meadows (Marba et al. 2015). However, Greiner et al (2013) found that meadows which had been restored 10 years ago as part of a seagrass restoration project in Chesapeake Bay, USA contained more carbon than bare sediments and 4-year old restorations; similar data are needed in the Australian context. Some cost-effective seagrass restoration methods have been developed, but seagrass restoration is still generally the most expensive among blue carbon habitats (Blandon and Ermgassen 2014; Hejnowicz et al. 2015). Therefore, it is much cheaper to maintain existing seagrass meadows and restore water quality to encourage natural recovery than directly fund the restoration of large seagrass meadows.

\subsection{Conclusion}

As policy supporting blue carbon is evolving rapidly, it is critical that science and observational data are used to inform these policy frameworks. For example, if and when a REDD-type policy is established for seagrasses, we will need to estimate C accumulation for a re-established meadow. Many nations are presently incorporating blue carbon into their broader GHG accounting schemes. Blue carbon accounting requires stocks and fluxes as well as estimates of processes including additionality, leakage, permanence, conversion and emission factors.

Development of seagrass carbon maps will assist with the impact assessment of coastal developments, where loss of carbon as well as seagrass community structure (and ecosystem services) will need to be mitigated. To extrapolate this new knowledge, biogeochemical models are currently being developed to predict blue carbon stock; where larger quantities of empirical data exist, the model estimates will be more accurate, whilst on-going improvements in remote sensing techniques will allow regular boundary updates of managed meadows.

\section{References}

ABS (2015) 4655.0-Australian Environmental-Economic Accounts. Explanatory notes. Retrieved 15 Feb 2016, from http://www.abs.gov.au/AUSSTATS/abs@.nsf/Lookup/4655. 0Explanatory\%20Notes12015?OpenDocument

Ajani J, Comisari P (2014) Towards a comprehensive and fully integrated stock and flow framework for carbon accounting in Australia. A discussion paper, Australian National University, Canberra, Australia, 78 pp 
Arkema KK, Guannel G, Verutes G, Wood SA, Guerry A, Ruckelshaus M, Kareiva P, Lacayo M, Silver JM (2013) Coastal habitats shield people and property from sea-level rise and storms. Nat Clim Change 3(10):913-918

Barbier EB, Hacker SD, Kennedy C, Koch EW, Stier AC, Silliman BR (2011) The value of estuarine and coastal ecosystem services. Ecol Monogr 81(2):169-193

Blandon A, Zu Ermgassen PS (2014) Quantitative estimate of commercial fish enhancement by seagrass habitat in southern Australia. Estuar Coast Shelf Sci 141:1-8

Cebrian J (2002) A blueprint for blue carbon: toward an improved understanding of the role of vegetated coastal habitats in sequestering $\mathrm{CO}_{2}$. Limnol Oceanogr 47:11-22

Conservation International (2015) The blue carbon initiative. Mitigating climate change through coastal ecosystem management. Retrieved 11 Oct, 2015, from http://thebluecarboninitiative.org/

Costanza R, d'Arge R, De Groot R, Farber S, Grasso M, Hannon B, Limburg K, Naeem S, O'neill RV, Paruelo J, Raskin RG (1997) The value of the world's ecosystem services and natural capital. Nature 387(6630):253-260

Duarte CM, Marba N, Gacia E, et al (2010) Seagrass community metabolism: assessing the carbon sink capacity of seagrass meadows. Global Biogeochem Cycles 24:GB4032

Enriquez S, Duarte CM, Sandjensen K (1993) Patterns in decomposition rates among photosynthetic organisms - the importance of detritus C-N-P content. Oecologia 94(4):457-471

Garrard SL, Beaumont NJ (2014) The effect of ocean acidification on carbon storage and sequestration in seagrass beds; a global and UK context. Mar Pollut Bull 86:138-146

Greiner JT, McGlathery KJ, Gunnell J, McKee BA (2013) Seagrass restoration enhances "blue carbon" sequestration in coastal waters. PLoS ONE 8(8):e72469

Grimsditch G, Kenchington R, Alder J, Tamelander J, Nakamura T (2013) The blue carbon special edition-introduction and overview. Ocean Coast Manag 83:1-4

Hejnowicz AP, Kennedy H, Rudd MA, Huxham MR (2015) Harnessing the climate mitigation, conservation and poverty alleviation potential of seagrasses: prospects for developing blue carbon initiatives and payment for ecosystem service programmes. Front Mar Sci 2:32

IOC/UNESCO, I, FAO, UNDP (2011) A blueprint for ocean and coastal sustainability. IOC/ UNESCO, Paris, $42 \mathrm{pp}$

Irving AD, Tanner JE, Seddon S, Miller D, Collings GJ, Wear RJ, Hoare SL, Theil MJ (2010) Testing alternate ecological approaches to seagrass rehabilitation: links to life-history traits. J Appl Ecol 47(5):1119-1127

Kennedy H, Beggins J, Duarte CM, Fourqurean JW, Holmer M, Marbà N, Middelburg JJ (2010) Seagrass sediments as a global carbon sink: Isotopic constraints. Global Biogeochem Cycles 24:GB4026

Lau WWY (2013) Beyond carbon: conceptualizing payments for ecosystem services in blue forests on carbon and other marine and coastal ecosystem services. Ocean Coast Manag 83:5-14

Lavery PS, Mateo MÁ, Serrano O, Rozaimi M (2013) Variability in the carbon storage of seagrass habitats and its implications for global estimates of blue carbon ecosystem service. PLoS ONE 8(9):e73748

Luisetti T, Jackson EL, Turner RK (2013) Valuing the European 'coastal blue carbon' storage benefit. Mar Pollut Bull 71(1-2):101-106

Macreadie PI, Allen K, Kelaher BP, Ralph PJ, Skilbeck CG (2012) Paleoreconstruction of estuarine sediments reveal human-induced weakening of coastal carbon sinks. Glob Change Biol 18(3):891-901

Macreadie PI, Baird ME, Trevathan-Tackett SM, Larkum AWD, Ralph PJ (2014) Quantifying and modelling the carbon sequestration capacity of seagrass meadows. Mar Pollut Bull 83(2): 430-439

Macreadie PI, Trevathan-Tackett SM, Skilbeck CG, Sanderman J, Curlevski N, Jacobsen G, Seymour JR (2015) Losses and recovery of organic carbon from a seagrass ecosystem following disturbance. Proc R Soc B 282:1817

Marba N, Arias-Ortiz A, Masque P, Kendrick GA, Mazarrasa I, Bastyan GR, Garcia-Orellana J, Duarte CM (2015) Impact of seagrass loss and subsequent revegetation on carbon sequestration and stocks. J Ecol 103(2):296-302 
Mateo MA, Cebrian J, Dunton K (2006) Carbon flux in seagrass ecosystems. In: Larkum AW, Orth RJ, Duarte CM (eds) Seagrasses: biology, ecology and conservation, pp 159-192

Mcleod E, Chmura GL, Bouillon S, Salm R, Björk M, Duarte CM, Lovelock CE, Schlesinger WH, Silliman BR (2011) A blueprint for blue carbon: toward an improved understanding of the role of vegetated coastal habitats in sequestering $\mathrm{CO}_{2}$. Front Ecol Environ 9(10):552-560

Nellemann C, Corcoran E, Duarte CM, Valdés L, De Young C, Fonseca L, Grimsditch G (eds) (2009) Blue carbon. A rapid response assessment. United Nations Environment Programme, GRID-Arendal, Norway, 79 pp. ISBN: 978-82-7701-060-1. http://www.grida.no/ files/publications/blue-carbon/BlueCarbon_screen.pdf

Orth RJ, Carruthers TJB, Dennison WC, Duarte CM, Fourqurean JW, Heck KL, Hughes AR, Kendrick GA, Kenworthy WJ, Olyarnik S, Short FT, Waycott M, Williams SL (2006) A global crisis for seagrass ecosystems. Bioscience 56(12):987-996

Pendleton L, Donato DC, Murray BC, Crooks S, Jenkins WA, Sifleet S, Craft C, Fourqurean JW, Kauffman JB, Marba N, Megonigal P, Pidgeon E, Herr D, Gordon D, Baldera A (2012) Estimating global blue carbon emissions from conversion and degradation of vegetated coastal ecosystems. PLoS ONE 7(9):e43542

Pendleton LH, Thébaud O, Mongruel RC, Levrel H (2016) Has the value of global marine and coastal ecosystem services changed? Mar Policy 64:156-158

Rozaimi M, Lavery PS, Serrano O, Kyrwood D (2016) Long-term carbon storage and its recent loss in a temperate estuarine Posidonia australis meadow. Estuar Coast Shelf Sci. https://doi. org/10.1016/j.ecss.2016.01.001

Selig ER, Turner WR, Troeng S, Wallace BP, Halpern BS, Kaschner K, Lascelles BG, Carpenter KE, Mittermeier RA (2014) Global priorities for marine biodiversity conservation. PLOS ONE 9(1):e82898

Serrano O, Lavery PS, Rozaimi M, Mateo MÁ (2014) Influence of water depth on the carbon sequestration capacity of seagrasses. Global Biogeochem Cycles 28:950-961. https://doi.org/ 10.1002/2014GB004872

Trevathan-Tackett SM, Seymour JR, Nielsen DA, Macreadie PI, Jeffries TC, Sanderman J, Baldock J, Howes JM, Steven AD, Ralph PJ (2017) Sediment anoxia limits microbial-driven seagrass carbon remineralization under warming conditions. FEMS Microbiol Ecol

Trevathan-Tackett SM, Kelleway J, Macreadie PI, Beardall J, Ralph P, Bellgrove A (2015) Comparison of marine macrophytes for their contributions to blue carbon sequestration. Ecology 96(11):3043-3057

Ullman R, Bilbao-Bastida V, Grimsditch G (2013) Including blue carbon in climate market mechanisms. Ocean Coast Manag 83:15-18

Waycott M, Duarte CM, Carruthers TJB, Orth RJ, Dennison WC, Olyarnik S, Calladine A, Fourqurean JW, Heck KL, Hughes AR, Kendrick GA, Kenworthy WJ, Short FT, Williams SL (2009) Accelerating loss of seagrasses across the globe threatens coastal ecosystems. PNAS 106(30):12377-12381

Zann LP (2000) The Eastern Australian region: a dynamic tropical/temperate biotone. Mar Pollut Bull 41:188-203 


\title{
Chapter 23 \\ Taxonomy of Australian Seagrasses
}

\author{
John Kuo, Marion L. Cambridge, Len J. McKenzie \\ and Robert G. Coles
}

\begin{abstract}
This chapter lists all Australian seagrass species with their synonyms, which are currently accepted by the IPNI (International Plant Name Index) and the Plant List; the world authority of plant taxonomy. It also briefly reviews taxonomic studies on the Australian seagrasses and includes keys to all Australian seagrass species, with the practical goal of providing botanists with a name for seagrass species based on morphological characteristics. With their limited range of morphological characters, even constructing a morphological key presents some difficulties. The Australian waters are rich in seagrass species (33), with more than one third of the described seagrass species in the world. The majority of Australian temperate species are endemic, while those occurring in Australian tropics are also distributed in the Indo-Pacific region. Where possible we consider the results of molecular phylogenies but at present these are incomplete, and have only focused on a limited range of species.
\end{abstract}

\footnotetext{
J. Kuo $(\bowtie)$

Centre for Microscopy, Microanalysis and Characterization,

The University of Western Australia, Crawley, Perth, WA 6009, Australia

e-mail: john.kuo@uwa.edu.au
}

M. L. Cambridge

The Oceans Institute and School of Plant Biology, The University of Western Australia, Crawley, Perth, WA 6009, Australia

e-mail: marion.cambridge@uwa.edu.au

\section{J. McKenzie · R. G. Coles}

Centre for Tropical Water and Aquatic Ecosystem Research, James Cook University, Cairns Campus, 14-88 McGregor Road Smithfield, PO Box 6811, Cairns,

QLD 4878, Australia

e-mail: len.mckenzie@jcu.edu.au

R. G. Coles

e-mail: rob.coles@jcu.edu.au 